УДК 616:521-036.1-071:615.015.8

«Журнал НАМН України» | 2021 | т. 27 | № 2 | С. 73-80

https:/doi.org/10.37621/JNAMSU-2021-2-1

\section{Вивчення показників} протимікробної резистентності

\section{у хворих}

\section{на алергодерматози,} обтяжені

стафрі^ококовою інфекцією,

за результатами тестів $з$ аутоштамами

\section{Я. Ф. Кутасевич, С. К. Джораєва , В. В. Гончаренко, І. О. Маштакова, О. В. Щоголєва, Н. В. Соболь}

ДУ «Інститут дерматології та венерологіі НАМН України», вул. Чернишевська 7/9, Харків 61057, Україна

Вступ. Актуальність дослідження обумовлена відсутністю даних щодо стану неспецифічного клітинного імунітету у дослідженнях 3 сироватками та аутоштамами S. aureus, виділеними від хворих на алергодерматози, які 6 відображали напруженість протимікробного імунітету у пацієнтів 3 алергодерматозами, обтяженими стафілококовою інфекцією, в залежності від ступеня тяжкості дерматозу.

Мета: визначення та аналіз показників протимікробного імунітету у хворих на атопічний дерматит та істинну екзему, обтяжених стафілококовою інфекцією, з використанням сироваток та аутоштамів S. aureus, в залежності від ступеня тяжкості захворювань.

Матеріал і методи. У дослідження було включено 107 пацієнтів 3 різним ступенем тяжкості алергодерматозів та 15 практично здорових осіб контрольної групи. Хворі розподілені на три групи в залежності від тяжкості перебігу шкірного процесу. У них було визначено основні показники початкових стадій фагоцитозу та кисеньзалежну бактерицидну активність фагоцитів. Для оцінки
Study of indicators of antimicrobial resistance in patients with allergodermatosis, complicated by staphylococcus infection, according to the results of tests with autostrains

Yanina F. Kutasevich, Svetlana K. Dzhoraeva , Valentina V. Goncharenko, Irina A. Maschtakova, Helen V. Shchegoleva, Natalia V. Sobol

SI «Institute of Dermatology and Venerology of National Academy of Medical Sciences of Ukraine», 7/9 Chernyshevska str., Kharkiv 61057, Ukraine

Introduction. The relevance of the study is due to the lack of data on the state of nonspecific cellular immunity in studies with sera and autostrains of S.aureus isolated from patients with allergic dermatoses, which would reflect the intensity of antimicrobial immunity in patients with allergic dermatoses, aggravated by staphylococcal infection, depending on the severity of dermatosis.

Aim: of the study was to determine and analyze the results of antimicrobial immunity indicators in patients with atopic dermatitis and true eczema, aggravated by staphylococcal infection, using sera and autostrains of S. aureus, depending on the severity of the disease. Material and methods. It was included 107 patients with different stage of the allergic dermatoses severity and control group of 15 healthy individuals to the research. The patients were divided into 3 groups in according to the severity of cutaneous process course. There were determined the basic indices of initial stages of phagocytosis and oxydepending bactericidal activity of the phagocytes. It was conducted the immunologic examinations using 
протимікробного імунітету проведено імунологічне обстеження 3 застосуванням власних штамів пацієнтів, вилучених 3 осередків ураження, та еталонного штаму S. aureus ATCC 25923.

Результати. Оцінка показників фагоцитозу у хворих на алергодерматози показала кореляцію між ступенем тяжкості хвороби та рівнем пригнічення клітинної ланки неспецифічного імунітету. За результатами досліджень із використанням аутоштамів S. aureus найбільш суттєве пригнічення фагоцитозу ( $p \leq 0,05)$, у порівнянні зі значеннями аналогічних показників у контрольній когорті здорових осіб, встановлено у групах хворих із помірним та важким ступенем тяжкості атопічного дерматиту (АД), відповідно: фагоцитарна активність $(Ф А)(78,1 \pm 1,4),(72,4 \pm 1,4)$ i $(71,7 \pm 0,8) \%$; фагоцитарне число (ФЧ) $(5,3 \pm 0,2),(4,3 \pm 0,2)$ i $(3,5 \pm 0,1)$ абсолютного числа (абс. ч.); фагоцитарний індекс (ФІ) $(6,8 \pm 0,2),(6,2 \pm 0,2)$ і $(4,8 \pm 0,1)$ абс. ч.; фагоцитарна ємність

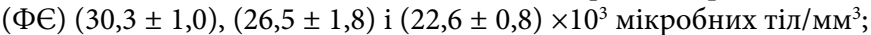
спонтанний тест відновлення нітросинього тетразолію (сНСТ) $(42,1 \pm 1,3),(48,1 \pm 1,2)$ і $(50,6 \pm 0,3) \%$; індукований (S. aureus) тест відновлення нітросинього тетразолію (іНСТ) $(63,4 \pm 1,6)$, $(53,4 \pm 0,8)$ i $(51,7 \pm 0,7) \%$. У хворих на істинну екзему (IE) виявлено подібну закономірність пригнічення фагоцитозу, найбільш виражену у пацієнтів із важким ступенем тяжкості захворювання $(p \leq 0,05)$, але 3 дещо меншим ступенем відмінності значень показників фагоцитозу у порівнянні із контрольною групою, відповідно: ФА $(74,8 \pm 1,3)$ і $(78,1 \pm 1,4) \%$; ФЧ $(4,5 \pm 0,1)$ i $(5,3 \pm 0,2)$ абс. ч.; $\Phi \mathrm{I}(5,9 \pm 0,2)$ i $(6,8 \pm 0,9)$ абс. ч.; сHCT $(46,0 \pm 0,6)$ i $(42,1 \pm 1,3) \%$; iHCT $(51,8 \pm 0,8)$ i $(63,4 \pm 1,6) \%$.

Висновки. Результати визначення показників фагоцитозу у хворих на алергодерматози із використанням еталонної культури S. aureus ATCC 25923 у цілому показують описані пригнічення у пацієнтів клітинної ланки неспецифічного імунітету, але є менш показовими для їх виявлення у порівнянні з аутоштамами.

Ключові слова: алергодерматози, тяжкість перебігу, аутоштами S. aureus, S. aureus ATCC 25923, протимікробна резистентність.

Для цитування: Кутасевич ЯФ, Джораєва СК, Гончаренко ВВ, Мачтакова IO, Щоголєва ОВ, Соболь НВ. Вивчення показників протимікробної резистентності у хворих на алергодерматози, обтяжені стафбілококовою інфекцією, за результатами тестів з аутоштамами. Журнал Наиіональної академії медичних наук України. 2021;27(2):73-80. https:/doi.org/10.37621/JNAMSU-2021-2-1.

Стаття надійшла до редакції 30.04.2021 року

Направлена на рецензування 12.07.2021 року

Прийнята до друку 15.07.2021 року

\section{ВІДОМОСТІ ПРО АВТОРІВ}

Кутасевич Яніна Францівна - д. М. Н., проф., директор Інституту, ORCID: 0000-0001-8706-1487;

Джораєва Світлана Карьягдиївна - Д. М. Н., завідувачка лабораторноекспериментального відділу, ORCID: 0000-0003-2486-5474

Гончаренко Валентина Василівна - К. М. Н., науковий співробітник лабораторії мікробіології, ORCID: 0000-0001-8168-0818;

Маштакова Ірина Олексіївна - К. М. Н., ст. наук. співр., старший науковий співробітник відділу дерматології, інфекційних та паразитарних захворювань шкіри, ORCID: 0000-0002-3592-6896;

щоголєва Олена Володимирівна - молодший науковий співробітник лабораторії мікробіології, ORCID: 0000-0002-7235-3556;

Соболь Наталя Володимирівна - лікар-бактеріолог клінікодіагностичної лабораторії, ORCID: 0000-0002-3622-0174. the autostrains patient from the locus morbi and standard strain S. aureus ATCC for the estimation of antimicrobial immunity.

Results. Evaluation of phagocytosis indices in patients with allergodermatoses showed a correlation between the severity of the disease course and the level of inhibition of the cellular level of nonspecific immunity. According to the results of studies using autostrains $S$. aureus, the most significant inhibition of phagocytosis $(p \leq 0.05)$, compared to the values of similar indicators in the control group of healthy individuals, it was found in the groups of patients with moderate and severe atopic dermatosis (AD) course, respectively: phagocytic activity $(\mathrm{PhA})(78.1 \pm 1.4)$ and $(72.4 \pm 1.4)$ and $(71.7 \pm 0.8) \%$; phagocytic number $(\mathrm{PhN})(5.3 \pm 0.2)$ and $(4.3 \pm 0.2)$ and $(3.5 \pm 0.1)$ absolute number (abs. num.); phagocytic index $(\mathrm{PhI})(6.8 \pm 0.2)$ and $(6.2 \pm 0.2)$ and $(4.8 \pm 0.1)$ abs. num.; phagocytic capacity $(\mathrm{PhC})(30.3 \pm 1.0)$ and $(26.5 \pm 1.8)$ and $(22.6 \pm 0.8) \times 10^{3}$ microbial cell $/ \mathrm{mm}^{3}$; spontaneous test of the renovation of nitroblue tetrazolium (sNBT) $(42.1 \pm 1.3)$ and $(48.1 \pm 1.2)$ and $(50.6 \pm 0.3) \%$; induction test of the renovation of nitroblue tetrazolium (iNBT) $(63.4 \pm 1.6)$ and $(53.4 \pm 0.8)$ and $(51.7 \pm 0.7) \%$. In the patients with true eczema (TE), they revealed a similar regularity of phagocytosis inhibition, most pronounced in patients with a severe disease course $(p \leq 0.05)$, but with a slightly smaller degree of difference between the indicator values of phagocytosis compared with the group of healthy individuals, respectively: $\mathrm{PhA}(74.8 \pm 1.3)$ and $(78.1 \pm 1.4) \%$; PhN $(4.5 \pm 0.1)$ and $(5.3 \pm 0.2)$ abs. num.; PhI $(5.9 \pm 0.2)$ and $(6.8 \pm 0.9)$ abs. num.; sNBT $(46.0 \pm 0.6)$ and $(42.1 \pm 1.3) \%$; iNBT $(51.8 \pm 0.8)$ and $(63.4 \pm 1.6) \%$.

Conclusions. The results of identification of phagocytosis in patients with allergodermatoses using the standard culture of S. aureus ATCC 25923 generally reflect the described regularities of inhibition in patients of the cellular level of nonspecific immunity, but are less presentable for their identification in comparison with the autostrains.

Keywords: allergic dermatoses, severity of the course, S aureus autostrains, S. aureus ATCC 25923, antimicrobial resistance.

For citation: Kutasevich YaF, Dzhoraeva SK, Goncharenko VV, Maschtakova IA, Shchegoleva EV, Sobol NV. Study of indicators of antimicrobial resistance in patients with allergodermatosis, complicated by Staphylococcus infection, according to the results of tests with autostrains. Journal of the National Academy of Medical Sciences of Ukraine. 2021;27(2):73-80. https:/doi.org/10.37621/JNAMSU-2021-2-1.

The article was received on 30.04 .2021

For review, 12.07.2021

Accepted for publication on 15.07.2021

\section{INFORMATION ABOUT AUTHORS}

Yanina F. Kutasevych - Dr. Sci. (Medicine), Prof., Director of the Institute, ORCID: 0000-0001-8706-1487;

Svetlana K. Dzhoraieva - Dr. Sci. (Medicine), Head of the Laboratory and Experimental Department, ORCID: 0000-0003-2486-5474;

Valentina V. Goncharenko - Cand. Sci. (Medicine), Researcher of the Laboratory of Microbiology, ORCID:0000-0001-8168-0818;

Irina A. Maschtakova - Cand. Sci. (Medicine), Associate Professor, Senior Researcher of the Department of Dermatology, Infectious and Parasitic Skin Diseases, ORCID: 0000-0002-3592-6896;

Helen V. Shchogoleva - Junior Researcher of the Laboratory of Microbiology, ORCID: 0000-0002-7235-3556,

Nataliya V. Sobol - Bacteriologist of the Clinical and Diagnostic Laboratory, ORCID: 0000-0002-3622-0174. 


\section{ВСТУП}

Поряд зі збільшенням поширеності алергічних захворювань в останні десятиліття реєструється і зростання числа хворих на атопічний дерматит (АД) та істинну екзему (IE) $[1,2]$. Згідно з даними ВООЗ, алергійні захворювання займають третє місце у світі після серцево-судинної та онкопатології [3]. Пацієнти різного віку, статі, роду діяльності та місця проживання страждають на різні форми АД. Ступінь тяжкості його визначається поширеністю, активністю шкірного процесу і приєднанням вторинної інфекції $[4,5]$.

Особливу роль відіграють суперантигени - інфекційні агенти грибкової, бактеріальної або вірусної етіології. Відомо, що шкіра 80-100 \% хворих на атопічний дерматит колонізована Staphylococcus aureus (S. aureus). Його екзотоксини здатні викликати загострення і підтримувати запальний процес в шкірі. Вони виступають як суперантигени, що активують Т-лімфоцити, клітини Лангерганса i макрофаги. Більш ніж у половини пацієнтів з АД виявлено Ig Е до стафілококових екзотоксинів. Призначення антибактеріальних препаратів може значно поліпшити перебіг захворювання, а зниження імунологічної реактивності сприяє формуванню персистентної інфекції $[6,7]$. При атопічному дерматиті - АД, ускладненому мікробним процесом шкіри, виявлено глибші зміни протибактеріального захисту за рахунок пригнічення антитілоутворення і фагоцитарної активності $[8,9]$.

Численні дослідження останніх десятиліть уточнили основні компоненти етіопатогенезу АД. За даними різних авторів, в основі розвитку захворювання лежить комплексна взаємодія між спадковою схильністю до розвитку АД, дефіцитом шкірного бар'єра, імунологічними розладами та, можливо, аутоімунними механізмами $[10,11]$. Також ці порушення призводять до імуносупресії, загострення і рецидивування захворювання $[12,13]$. Зважаючи на важливість імунологічних порушень в етіопатогенезі АД, вивчення показників специфічного клітинного імунітету у пацієнтів з АД є необхідним аспектом для оцінки тяжкості його перебігу, прогнозу рецидивування і розвитку ускладнень.

В останні роки спостерігається тенденція до більш важкого клінічного перебігу екземи, що характеризується збільшенням площі ураження шкіри, появою торпідності до лікування, формуванням схильності до хронізації патологічного процесу з розвитком важких ускладнень, що, своєю чергою, призводить до погіршення якості життя пацієнта $[14,15]$. Згідно з сучасними дослідженнями, патогенез екземи є складним і багатофакторним. На розвиток екземи впливають екзогенні та ендогенні фактори, у тому числі імунологічні розлади, порушення ендокринної регуляції, захворювання травної системи, зміни кровообігу, та наявність осередків хронічної інфекції $[16,17]$.

Мультифакторний етіопатогенез атопічного дерматиту та істинної екземи засвідчує комплексний характер порушень з боку багатьох систем організму пацієнтів, а дослідження останніх років свідчать про суттєві імунні розлади у хворих на алергодерматози, що стосуються гумо- ральної й клітинної ланок імунітету $[15,18]$. На сьогодні досить важливими видаються зміни, що спостерігаються в показниках неспецифічної резистентності організму, які відіграють важливу роль у розвитку алергодерматозів та набутті цими захворюваннями хронічного характеру, але ïх роль в патогенезі означених захворювань не може вважатися цілком зрозумілою $[12,19]$. Крім того, дані, які наведені у літературі, щодо індексів фагоцитарної активності клітин крові у пацієнтів 3 алергодерматозами є часто неоднозначними і суперечливими $[16,20]$. Також на сьогодні відсутні дані щодо стану неспецифічного клітинного імунітету хворих на алергодерматози, обтяжені стафілококовою інфекцією, в залежності від ступеня тяжкості дерматозу, які 6 показували напруженість протимікробного імунітету.

Метою дослідження було визначення та аналіз показників протимікробного імунітету у хворих на АД та IE, обтяжені стафілококовою інфекцією, 3 використанням сироваток та аутоштамів S. aureus, в залежності від ступеня тяжкості захворювань.

\section{МАТЕРІАЛИ ТА МЕТОДИ}

У дослідження було включено 107 пацієнтів з різним ступенем тяжкості алергодерматозів, з них 45 хворих на АД та 62 пацієнти з IE, що знаходились на стаціонарному лікуванні у відділенні дерматології ДУ «ІДВ НАМНУ», контрольну групу склали 15 осіб репрезентативного віку та статі.

Усім пацієнтам з АД було проведено визначення бальної оцінки тяжкості дерматозу за допомогою напівкількісної шкали Scoring Atopic Dermatitis (SCORAD), що дозволяє оцінити площу ураження тіла та інтенсивність клінічних проявів сумісно з суб'єктивними симптомами свербежем і порушенням сну. Залежно від величини індексу SCORAD хворі розподілялися на три групи за ступенем тяжкості перебігу шкірного процесу [21].

Клінічну картину тяжкості IE оцінювали за допомогою індексу тяжкості захворювання і площі ураження при екземі Eczema Area and Severity Index (EASI) [22].

3 метою оцінки стану неспецифічної резистентності організму у хворих на АД та IE було визначено основні показники фагоцитозу, фагоцитарну активність (ФА), фагоцитарний індекс (ФІ), фагоцитарне число (ФЧ), фагоцитарну ємність $(Ф €)$, що характеризують початкові стадії фагоцитозу. Кисеньзалежну бактерицидну активність фагоцитів визначали за допомогою спонтанного та індукованого (S. aureus) тесту відновлення нітросинього тетразолію (сНСТ-тест та іНСТ-тест), що характеризують здатність до початку та завершення фагоцитозу [23].

Пацієнти основної групи були розподілені на підгрупи в залежності від ступеня тяжкості захворювання. Означеним хворим було проведено імунологічне обстеження 3 оцінкою протимікробного імунітету 3 застосуванням власних штамів пацієнтів, вилучених з осередків ураження (locus morbi), тобто аутоштамів S. aureus та контрольного штаму Американської колекції типових культур, тобто еталонного штаму S. aureus ATCC 25923. У контрольній групі осіб у якості аутоштамів використовували 
еталонний штам S. aureus ATCC 25923 для порівняння показників фагоцитозу, визначених для обстежених.

Дослідження виконані згідно з Гельсінською декларацією Всесвітньої медичної асоціації про етичні принципи медичних досліджень за участю людини.

Статистичну обробку отриманих результатів проводили $з$ використанням пакету прикладних програм для Microsoft Excel 2003. Аналіз якісних даних проводили за допомогою критерію $\chi^{2}$. Вираховували середні арифметичні значення для ряда даних (M) і похибки середніх величин (m). Вірогідність отриманих даних оцінювали шляхом парного порівняння та визначення довірчого інтервалу на підставі розрахунку коефіцієнта Стьюдента (t). Відмінності вважали вірогідно значущими при $p \leq 0,05$.

\section{РЕЗУЛЬТАТИ ТА ОБГОВОРЕННЯ}

На першому етапі дослідження було проведено визначення мікробіоценозу шкіри хворих на алергодерматози в залежності від ступеня тяжкості дерматозу. У результаті проведених досліджень у хворих на АД встановлена пряма залежність між частотою вилучення S. aureus, як 3 осередків ураження, так і інтактних ділянок шкіри, та ступенем тяжкості дерматозу: 46,7 \% та 38,5 \% при легкому ступені тяжкості АД 59,4\% і 45,2 \% при помірному та 81,8 \% і 70,4 \% при важкому. При цьому частота вилучення S. epidermidis мала зворотню залежність: 20,0 \% і 30,8 \%; $15,6 \%$ і $19,4 \%$ та 10,9 \% і 16,7 \%, відповідно. У хворих на IЕ частота ізоляцій S. aureus корелювала зі ступенем тяжкості дерматозу тільки при вивченні матеріалу з уражених ділянок шкіри: 28,6 \% при легкому ступеню тяжкості, 36,4 \% при помірному та 53,2 \% при важкому. Отримані дані демонструють спорідненість мікробних ускладнень шкіри при означених алергодерматозах, а особливо наочні результати отримані для хворих на АД [24, 25].

При вивченні показників стану клітинної ланки неспецифічного імунітету у хворих на АД та IE встановлено пригнічення фагоцитозу (у порівнянні із контрольною групою), що корелювало зі ступенем тяжкості дерматозу (табл. 1).

Оцінка стану фагоцитозу у хворих на АД у дослідженнях 3 використанням аутоштамів свідчила про помітне зниження показників у групах хворих з помірним та важким ступенем тяжкості захворювання: показник ФА дорівнював відповідно $(72,4 \pm 1,4) \%$ і $(71,7 \pm 0,8) \%$ та був вірогідно нижче аналогічного у контрольній групі $(78,1 \pm 1,4) \%$; показник ФЧ склав $(4,3 \pm 0,2)$ абсолютного числа (абс. ч.) та $(3,5 \pm 0,1)$ абс. ч. проти $(5,3 \pm 0,2)$ абс. ч. у контрольній групі; значення ФІ дорівнювало $(6,2 \pm 0,2)$ абс. ч. та $(4,8 \pm 0,1)$ абс. ч. проти $(6,8 \pm 0,2)$ абс. ч. у групі здорових осіб ( $p \leq 0,05)$ (табл. 1$)$.

Аналогічну тенденцію ми спостерігали при визначенні $\Phi €$ в експерименті з аутоштамами: попри підвищення загальної кількості лейкоцитів у хворих з помірним та важким ступенем тяжкості захворювання $\left[(6,3 \pm 0,2) \times 10^{3}\right.$

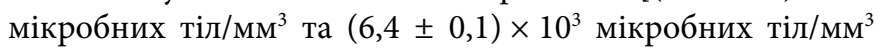

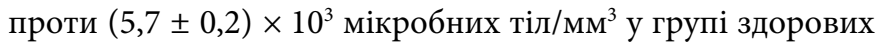
осіб)], даний показник мав тенденцію до зниження, особливо це помітно у групі хворих з важким ступенем тяжко- сті АД внаслідок зниження ФІ $[(27,6 \pm 0,6)$ абс. ч. проти $(30,3 \pm 1,0)$ абс. ч. у групі здорових осіб].

При проведенні обстеження хворих на АД з використанням еталонного штаму S. aureus ATCC 25923 спостерігалась подібна тенденція, але $з$ нижчими абсолютними значеннями. 3 порівняння означених показників у пацієнтів з легким ступенем тяжкості АД з використанням аутоштамів та еталонного штаму S. aureus ATCC 25923 не було вірогідних відмінностей у значеннях цих показників, на відміну від групи хворих з важким ступенем тяжкості АД. Так, ФЧ в експерименті з аутоштамами дорівнювало $(3,5 \pm 0,1)$ абс. ч. проти $(4,5 \pm 0,6)$ абс. ч. в експерименті 3 еталонним штамом S. aureus ATCC 25923 ( $p \leq 0,001)$; ФI склав $(4,8 \pm 0,1)$ абс. ч. проти $(6,1 \pm 0,2)$ абс. ч. $(p \leq 0,001)$; $Ф €$ була на рівні $(22,6 \pm 0,8) \times 10^{3}$ мікробних тіл/мм ${ }^{3}$ проти $(27,6 \pm 0,6) \times 10^{3}$ мікробних тіл/мм ${ }^{3}$, що свідчить про суттєве пригнічення клітинної ланки імунітету у даної групи хворих. Тобто є кореляція між ступенем тяжкості дерматозу та погіршенням стану неспецифічного клітинного імунітету, що особливо наочно продемонстровано при проведенні досліджень з використанням аутоштамів.

Окрім того, відмічено вірогідне збільшення сНСТтесту у групах з помірним та важким ступенем тяжкості АД в експерименті 3 аутоштамими - $(48,1 \pm 1,2) \%$ i $(50,6 \pm 0,3) \%$ проти $(41,2 \pm 1,3) \%$ у контролі. Також визначено вірогідну різницю у показниках сНСТ у групі хворих 3 важким перебігом АД при використанні аутоштамів у порівнянні з еталонним штамом S. aureus ATCC 25923: $(50,6 \pm 0,3) \%$ проти $(45,4 \pm 1,0) \%(p \leq 0,001)$.

Активація сНСТ-тесту у хворих з помірним та важким ступенем тяжкості АД може бути обумовлена сильною антигенною стимуляцією поліморфноядерних лейкоцитів в умовах обтяження АД стафілококовою інфекцією, на тлі вірогідного зниження показників іНСТ-тесту $[(51,7 \pm 0,7) \%$ i $(53,4 \pm 0,8)$ \% проти $(63,4 \pm 1,6) \%$ у контролі], що напевно пов'язано зі стійким пригніченням активності нейтрофільних гранулоцитів. Особливо це помітно з порівняння показника у групі хворих з важким перебігом АД в експерименті з аутоштамами - $(51,7 \pm 0,7) \%$ проти $(59,7 \pm 0,4) \%$ у експерименті з еталонним штамом S. aureus ATCC 25923 $(p \leq 0,001)$. Тобто клітини приходять у стан, коли вони не можуть мобілізувати свій ефекторний потенціал та відповідати розвитком «респіраторного вибуху» 3 напрацюванням активних форм кисню. При цьому показники фагоцитозу у групі хворих з легким ступенем тяжкості АД не мали вірогідних відмінностей у порівнянні з контрольною групою, як в експерименті з аутоштамами, так і у дослідженні з еталонним штамом S. aureus ATCC, за винятком іНСТ, де спостерігалась вірогідна різниця у значеннях показника: $(57,6 \pm 1,1) \%$ і $(63,4 \pm 1,6) \%$ відповідно $(p \leq 0,05)$, та $(59,1 \pm 0,7)$ i $(63,4 \pm 1,6) \%$ відповідно $(p \leq 0,05)$.

У табл. 2 наведено дані щодо вивчення показників фагоцитозу у хворих на IE в залежності від ступеня тяжкості захворювання.

При аналізі рівня фагоцитозу у хворих на IE було визначено аналогічні зміни у показниках фагоцитозу, як i при АД, але меншого ступеня вираженості, при цьому вони стосувались переважно хворих з тяжкими проявами 


\section{ТАБЛИЦЯ 1 / ТАВLE 1}

ПОКАЗНИКИ ФАГОЦИТОЗУ У ХВОРИХ НА АД В ЗАЛЕЖНОСТІ ВІД СТУПЕНЯ ТЯЖКОСТІ ЗАХВОРЮВАННЯ (М \pm m) / INDICATORS OF PHAGOCYTOSIS IN PATIENTS WITH AD ACCORDING TO THE SEVERITY OF THE DISEASE (M $\pm \mathrm{m})$

\begin{tabular}{|c|c|c|c|c|c|c|c|}
\hline \multirow[b]{2}{*}{$\begin{array}{l}\text { Показники фагоцитозу / } \\
\text { Indicators of phagocytosis }\end{array}$} & \multirow[b]{2}{*}{$\begin{array}{c}\text { Контрольна } \\
\text { група / } \\
\text { Control } \\
\text { group } \\
\text { (n = 15), } \\
\text { S. aureus } \\
\text { ATCC 25923 }\end{array}$} & \multicolumn{6}{|c|}{ Хворі на АД / Patients with AD ( $=45)$} \\
\hline & & $\begin{array}{c}\text { Легкий } \\
\text { ступінь } \\
\text { тяжкості / } \\
\text { Mild } \\
\text { severity } \\
\text { (n=8), } \\
\text { autostrains } \\
\text { S. aureus }\end{array}$ & \begin{tabular}{|c|} 
Легкий \\
ступінь \\
тяжкості / \\
Mild \\
severity \\
(n=8), \\
S. aureus \\
ATCC 25923
\end{tabular} & $\begin{array}{l}\text { Помірний } \\
\text { ступінь } \\
\text { тяжкості / } \\
\text { Moderate } \\
\text { severity } \\
\text { (n=17), } \\
\text { autostrains } \\
\text { S. aureus }\end{array}$ & $\begin{array}{c}\text { Помірний } \\
\text { ступінь } \\
\text { тяжкості / } \\
\text { Moderate } \\
\text { severity } \\
\text { (n= 17), } \\
\text { S. aureus } \\
\text { ATCC 25923 }\end{array}$ & $\begin{array}{c}\text { Важкий } \\
\text { ступінь } \\
\text { тяжкості / } \\
\text { Severe } \\
\text { severity } \\
\text { (n=20), } \\
\text { autostrains } \\
\text { S. aureus }\end{array}$ & $\begin{array}{l}\text { Важкий } \\
\text { ступінь } \\
\text { тяжкості / } \\
\text { Severe } \\
\text { severity } \\
\text { (n=20), } \\
\text { S. aureus } \\
\text { ATCC 25923 }\end{array}$ \\
\hline ФA (\%) / Phagocytic activity, \% & $78,1 \pm 1,4$ & $76,0 \pm 1,6$ & $78,1 \pm 1,4$ & $72,4 \pm 1,4^{*}$ & $75,2 \pm 1,6$ & $71,7 \pm 0,8^{*}$ & $72,4 \pm 1,7^{*}$ \\
\hline $\begin{array}{l}\text { ФЧ (абс. ч.) / Phagocytic } \\
\text { number, abs. num. }\end{array}$ & $5,3 \pm 0,2$ & $4,9 \pm 0,2^{*}$ & $5,0 \pm 0,3$ & $4,3 \pm 0,1^{*}$ & $4,8 \pm 0,2^{* *}$ & $3,5 \pm 0,1^{*}$ & $4,5 \pm 0,6^{* *}$ \\
\hline $\begin{array}{l}\text { ФI (абс. ч.) / Phagocytic index, } \\
\text { abs. num. }\end{array}$ & $6,8 \pm 0,2$ & $6,4 \pm 0,3^{*}$ & $6,5 \pm 0,3$ & $6,2 \pm 0,2 *$ & $6,4 \pm 0,2^{*}$ & $4,8 \pm 0,1^{*}$ & $6,1 \pm 0,2^{* *}$ \\
\hline $\begin{array}{l}\text { Загальна кількість лейкоцитів } \\
\left(\times 10^{9} / л\right) / \text { Total white blood cell } \\
\text { count, } \times 10^{9} / \mathrm{L}\end{array}$ & $5,7 \pm 0,2$ & $5,8 \pm 0,1$ & $5,7 \pm 0,2$ & $6,3 \pm 0,2^{*}$ & $6,1 \pm 0,2^{*}$ & $6,4 \pm 0,1$ & $6,1 \pm 0,1^{*}$ \\
\hline $\begin{array}{l}\text { Ф }\left(\times 10^{3} \text { мікробних тіл/мм³ }\right) / \\
\text { Phagocytic capacity, } \times 10^{3} \\
\text { microbial cell } / \mathrm{mm}^{3}\end{array}$ & $30,3 \pm 1,0$ & $27,5 \pm 1,4$ & $28,1 \pm 0,9$ & $26,5 \pm 1,8$ & $28,3 \pm 1,0$ & $22,6 \pm 0,8^{*}$ & $27,6 \pm 0,6^{* *}$ \\
\hline $\begin{array}{l}\mathrm{sHCT}(\%) / \text { Spontaneous test of } \\
\text { the renovation of nitroblue } \\
\text { tetrazolium, } \%\end{array}$ & $42,1 \pm 1,3$ & $45,6 \pm 0,6$ & $43,7 \pm 0,8$ & $48,1 \pm 1,2^{*}$ & $46,2 \pm 1,2$ & $50,6 \pm 0,3^{* *}$ & $45,4 \pm 1,0^{*}$ \\
\hline $\begin{array}{l}\mathrm{iHCT}(\%) \text { / Induction test of the } \\
\text { renovation of nitroblue } \\
\text { tetrazolium, \% }\end{array}$ & $63,4 \pm 1,6$ & $57,6 \pm 1,1^{*}$ & $59,1 \pm 0,7^{*}$ & $53,4 \pm 0,8^{*}$ & $55,4 \pm 0,8^{*}$ & $51,7 \pm 0,7^{*}$ & $59,7 \pm 0,4^{* *}$ \\
\hline
\end{tabular}

Примітка / Note: * - вірогідність відмінності показників фагоцитозу у хворих на АД порівняно з контрольною групою осіб (р $\leq 0,02) ; *$ _ вірогідність відмінності показників фагоцитозу, визначених у експерименті з аутоштамами та еталонним итамом S. аигеи АТСС 25923 $(p \leq 0,05) /^{*}$ - the probability of differences in phagocytosis in patients with $A D$, according to the control group of individuals $(p \leq 0.02)$; ${ }^{* *}-$ the probability of differences in phagocytosis parameters determined in the experiment with autostrains and the reference strain of S. aureus ATCC 25923 ( $p \leq 0.05$ ).

IE (табл. 2). Так, лише у групі хворих з важким ступенем тяжкості IE показники ФА та ФІ в експерименті з аутоштамами були вірогідно нижче у порівнянні 3 контрольною групою - $(74,8 \pm 1,3) \%$ проти $(78,1 \pm 1,4) \%(p \leq 0,05) \mathrm{i}$ $(5,9 \pm 0,2)$ абс. ч. проти $(6,8 \pm 0,9)$ абс. ч. у групі здорових осіб, відповідно $(p \leq 0,01)$; показник ФЧ у групах 3 помірним та важким ступенем тяжкості IE склав $(5,0 \pm 0,2)$ абс. ч. та $(4,5 \pm 0,1)$ абс. ч. проти $(5,3 \pm 0,2)$ абс. ч. у контрольній групі ( $p \leq 0,05)$. Також відмічено збільшення показників сHСТ-тесту у групі хворих з важким ступенем тяжкості IE у експерименті 3 аутоштамами - $(46,0 \pm 0,6) \%$ проти $(42,1 \pm 1,3) \%$ у групі здорових осіб $(p \leq 0,05)$ та вірогідне зниження показників іНСТ тесту - $(51,8 \pm 0,8) \%$ проти $(63,4 \pm 1,6) \%$, відповідно $(p \leq 0,001)$.

3 порівняння означених показників у пацієнтів з легким ступенем тяжкості IE, як з використанням аутоштамів, так і еталонного штаму S. aureus ATCC 25923 не було виявлено вірогідних відмінностей у значеннях цих показників. Порівняння показників фагоцитозу у хворих 3 важким ступенем тяжкості IE виявило достовірну різницю по окремих показниках: так ФЧ в експерименті 3 аутоштамами склало $(4,5 \pm 0,1)$ абс. ч. проти $(4,8 \pm 0,1)$ абс. ч. у дослідженнях 3 еталонним штамом $S$. aureus ATCC 25923 ( $p \leq 0,001)$; ФІ дорівнював $(5,9 \pm 0,2)$ абс. ч. проти
$(6,4 \pm 0,2)$ абс. ч. $(p \leq 0,1)$ відповідно. Також виявлено вірогідну різницю у показниках сНСТ - $[(43,9 \pm 0,9) \%$ та $(46,0 \pm 0,6) \%$, відповідно $(p \leq 0,01)]$ та іНСТ $[(51,8 \pm 0,8) \%$ та $(56,5 \pm 0,5) \%$ відповідно $(p \leq 0,001)]$.

У результаті проведених досліджень встановлено, що визначення стану протимікробної резистентності у хворих на алергодерматози, обтяжені стафілококовою інфекцією, доцільно проводити у форматі «аутоштам - пацієнт» для максимальної персоналізації отриманих даних, особливо у хворих з важким ступенем тяжкості захворювань. Окрім того, показано, що зміни імунологічної реактивності у пацієнтів з АД були більш вираженими, ніж у пацієнтів 3 IE, що проявилося значним пригніченням практично усіх показників функціональної активності лейкоцитів крові (як показників фагоцитарної реакції, так і спонтанного та індукованого НСТ-тесту) від помірного до важкого, що особливо наочно у групі хворих 3 важким ступенем тяжкості АД. За результатами проведеного дослідження доведено, що у пацієнтів з АД та IE в стадії загострення спостерігається формування імунодефіцитного стану, який проявляється зниженням фагоцитарної активності лейкоцитів, що, в свою чергу, може бути показанням для включення у склад комплексного лікування імунокоригувальної терапії. 


\section{ТАБЛИЦЯ 2 / ТАВLE 2}

ПОКАЗНИКИ ФАГОЦИТОЗУ У ХВОРИХ НА ІЕ В ЗАЛЕЖНОСТІ ВІД СТУПЕНЯ ТЯЖКОСТІ ЗАХВОРЮВАННЯ / INDICATORS OF PHAGOCYTOSIS IN PATIENTS WITH TE ACCORDING TO THE SEVERITY OF THE DISEASE

\begin{tabular}{|c|c|c|c|c|c|c|c|}
\hline \multirow[b]{2}{*}{$\begin{array}{l}\text { Показники фагоцитозу / } \\
\text { Indicators of phagocytosis }\end{array}$} & \multirow[b]{2}{*}{$\begin{array}{c}\text { Контроль } \\
\text { на група / } \\
\text { Control } \\
\text { group } \\
(\mathbf{n}=15), \\
\text { S. aureus } \\
\text { ATCC } \\
25923\end{array}$} & \multicolumn{6}{|c|}{ Хворі на IE / Patients with TE ( $n=45)$} \\
\hline & & $\begin{array}{c}\text { Легкий } \\
\text { ступінь } \\
\text { тяжкості / } \\
\text { Mild } \\
\text { severity } \\
\text { (n=10), } \\
\text { autostrains } \\
\text { S. aureus }\end{array}$ & $\begin{array}{c}\text { Легкий } \\
\text { ступінь } \\
\text { тяжкості / } \\
\text { Mild } \\
\text { severity } \\
\text { (n= 10), } \\
\text { S. aureus } \\
\text { ATCC 25923 }\end{array}$ & $\begin{array}{l}\text { Помірний } \\
\text { ступінь } \\
\text { тяжкості / } \\
\text { Moderate } \\
\text { severity } \\
\text { (n=23), } \\
\text { autostrains } \\
\text { S. aureus }\end{array}$ & $\begin{array}{l}\text { Помірний } \\
\text { ступінь } \\
\text { тяжкості / } \\
\text { Moderate } \\
\text { severity } \\
\text { (n=23), } \\
\text { S. aureus } \\
\text { ATCC } 25923\end{array}$ & $\begin{array}{c}\text { Важкий } \\
\text { ступінь } \\
\text { тяжкості / } \\
\text { Severe } \\
\text { severity } \\
\text { (n=29), } \\
\text { autostrains } \\
\text { S. aureus }\end{array}$ & $\begin{array}{c}\text { Важкий } \\
\text { ступінь } \\
\text { тяжкості / } \\
\text { Severe } \\
\text { severity } \\
\text { (n= 29), } \\
\text { S. aureus } \\
\text { ATCC 25923 }\end{array}$ \\
\hline ФA (\%) / Phagocytic activity, \% & $78,1 \pm 1,4$ & $77,9 \pm 0,8$ & $78,7 \pm 0,7$ & $76,1 \pm 1,5$ & $77,8 \pm 1,8$ & $74,8 \pm 1,3^{*}$ & $76,7 \pm 1,4$ \\
\hline $\begin{array}{l}\text { ФЧ (абс. ч.) / Phagocytic } \\
\text { number, abs. num. }\end{array}$ & $5,3 \pm 0,2$ & $5,2 \pm 0,2$ & $5,3 \pm 0,1$ & $5,0 \pm 0,2$ & $5,1 \pm 0,2$ & $4,5 \pm 0,1^{*}$ & $4,8 \pm 0,1^{*}$ \\
\hline $\begin{array}{l}\text { ФI (абс. ч.) / Phagocytic index, } \\
\text { abs. num. }\end{array}$ & $6,8 \pm 0,2$ & $6,7 \pm 0,3$ & $6,8 \pm 0,2$ & $6,5 \pm 0,3$ & $6,6 \pm 0,2$ & $5,9 \pm 0,2^{*}$ & $6,4 \pm 0,2^{*}$ \\
\hline $\begin{array}{l}\text { Загальна кількість лейкоцитів } \\
\left(\times 10^{9} / л\right) / \text { Total white blood cell } \\
\text { count, } \times 10^{9} / \mathrm{L}\end{array}$ & $5,7 \pm 0,2$ & $5,8 \pm 0,1$ & $5,9 \pm 0,1$ & $6,0 \pm 0,1$ & $6,1 \pm 0,1$ & $6,3 \pm 0,7$ & $6,2 \pm 0,1$ \\
\hline $\begin{array}{l}\text { Ф }\left(\times 10^{3} \text { мікробних тіл/мм }{ }^{3}\right) / \\
\text { Phagocytic capacity, } \times 10^{3} \\
\text { microbial cell } / \mathrm{mm}^{3}\end{array}$ & $30,3 \pm 1,0$ & $30,8 \pm 0,9$ & $31,5 \pm 0,8$ & $29,8 \pm 0,8$ & $29,6 \pm 0,7$ & $28,0 \pm 0,7$ & $29,9 \pm 0,8$ \\
\hline $\begin{array}{l}\mathrm{CHCT}(\%) / \text { Spontaneous test of } \\
\text { the renovation of nitroblue } \\
\text { tetrazolium, \% }\end{array}$ & $42,1 \pm 1,3$ & $44,7 \pm 0,9$ & $42,9 \pm 0,8$ & $44,8 \pm 0,8$ & $42,2 \pm 0,7$ & $46,0 \pm 0,6^{*}$ & $43,9 \pm 0,9^{* *}$ \\
\hline $\begin{array}{l}\mathrm{iHCT}(\%) / \text { Induction test of the } \\
\text { renovation of nitroblue } \\
\text { tetrazolium, \% }\end{array}$ & $63,4 \pm 1,6$ & $58,3 \pm 1,2$ & $60,5 \pm 0,7$ & $56,3 \pm 0,5^{*}$ & $57,5 \pm 0,7^{* *}$ & $51,8 \pm 0,8^{*}$ & $56,5 \pm 0,5^{* *}$ \\
\hline
\end{tabular}

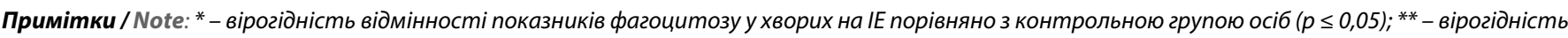
відмінності показників фагоцитозу, визначених у експерименті з аутоштамами та еталонним штамом S. aureus ATCC 25923 ( $p \leq 0,05$ ) / * - the probability of differences in phagocytosis in patients with TE compared with the control group ( $\leq \leq 0.05)$; ** the probability of differences in phagocytosis parameters determined in the experiment with autostrains and the reference strain of S. aureus ATCC $25923(p \leq 0.05)$.

\section{ВИСНОВКИ}

У хворих на алергодерматози відзначено суттєве пригнічення клітинної ланки неспецифічного імунітету, що підтверджується зниженням функціональної активності лейкоцитів крові. При проведенні порівняльних досліджень з використанням аутоштамів S. aureus та еталонного штаму S. aureus ATCC 25923 встановлено, що рівень пригнічення показників фагоцитозу більш виражений у разі застосування аутоштамів, вилучених із locus morbi $(p \leq 0,05)$. У порівнянні з контрольною групою здорових осіб найбільш суттєве пригнічення фагоцитозу встановлено у групах хворих із помірним та важким ступенем тяжкості АД. У хворих на IE виявлено подібну закономірність пригнічення фагоцитозу, найбільш виражену у пацієнтів із важким ступенем тяжкості захворювання, але 3 дещо меншим ступенем відмінності значень показників у порівнянні із групою здорових осіб.

Обмеження дослідження. У дослідження були включені дорослі пацієнти на алергодерматози з діагнозом АД (L 20.0) та IE (L 30.0 - інші дерматити) згідно з Міжнародним класифікатором хвороб 10. У дослідження не включали пацієнтів молодше 18 років, пацієнтів у стадії клінічної ремісії алергодерматозів, а також пацієнтів з загостренням хронічної соматичної хвороби на момент обстеження.

Перспективи подальших досліджень. Подальші дослідження сприятимуть розробці персоналізованої імунокоригувальної терапії з урахуванням стану протимікробної резистентності у хворих на тяжкі форми перебігу алергодерматозів. 
1. Soloshenko EM, Stulii OM, Roshchenyuk LV, Amer LB, Knyzhenko LB, Volkova NS et al. [Morbidity on widespread dermatosis from data of appeal in medical establishments of dermatovenerological and allergic profile in Kharkiv]. Journal of dermatovenerology and kosmetology n. N. A. Torsuev. 2014 June 6;12(34):35-40. Ukrainian.

2. Sybilski AJ, Raciborski F, Lipiec A, Tomaszewska A, Lusawa A, Samel-Kowalik P et al. Atopic dermatitis is a serious health problem in Poland. Epidemiology studies based on the ECAP study. Postepy Dermatol Alergol. 2015 Feb 2;32(1):1-10. DOI: 10.5114/pdia.2014.40935.

3. Chiesa Fuxench ZC, Block JK, Boguniewicz M, Boyle J, Fonacier L, Gelfand JM et al. Atopic dermatitis in America Study: A cross-sectional study examining the prevalence and disease burden of atopic dermatitis in the US adult population. J Invest Dermatol. 2019;139(3):583-90. DOI: $10.1016 /$ j.jid.2018.08.028

4. Stevens NE, Cowin AJ, Kopecki Z. Skin barrier and autoimmunity - mechanisms and novel therapeutic approaches for autoimmune blistering diseases of the skin. Front Immunol. 2019 May 14;10:1089. DOI: 10.3389/fimmu.2019.01089.

5. Paller AS, Kong HH, Seed P, Naik S, Scharschmidt TC, Gallo RL et. al. The microbiome in patients with atopic dermatitis. J Allergy Clin Immunol. 2019;143(1):26-35.

DOI: $10.1016 /$ j.jaci.2018.11.015

6. Egawa G, Kabashima K. Multifactorial skin barrier deficiency and atopic dermatitis: Essential topics to prevent the atopic march. J Allergy Clin Immunol. 2016 Jun 22;138(2):350-8.

DOI: $10.1016 /$ j.jaci.2016.06.002.

7. Tamrazova OB, Gureeva MA, Kuznetsova TA, Vorobeva AS. [Age evolutionary dynamics of atopic dermatitis]. Pediatry. 2016 Jan. 25;95(2):153-9. Russian.

8. Zhiltsova EE, Chakhoyan IR. [Role of immunological disturbances in development of atopic dermatitis]. Investigations and praktice in medicine. 2018;5(1):45-51. DOI: 10.17709/24092231-2018-5-1-5. Russian.

9. Weidinger S, Novak N. Atopic dermatitis. Lancet. 2016 Mar 12;387(10023):1109-22. DOI: $10.1016 /$ S0140-6736(15)00149.

10. Seite $S$, Bieber T. Barrier function and microbiotic dysbiosis in atopic dermatitis. Clin Cosmet Investig Dermatol. 2015 Sep 15;8:479-83. DOI: 10.2147/CCID.S91521.

11. Chen YE, Fischbach MA, Belkaid Y. Skin microbiota-host interactions. Nature. 2018 Jan 24;553(7689):427-36. DOI: $10.1038 /$ nature 25177 .

12. Yamazaki E, Kikuchi K, Sasahara Y, Kono M, Akiyama M, Aiba S. Atopic dermatitis without serum immunoglobulin E elevation or loss-offunction filaggrin gene mutation in a patient with $\mathrm{X}$-linked agammaglobulinemia. J Dermatol. 2020 Nov 27;47(1):58-60. DOI: 10.1111/13468138.15154

13. Barbarot S, Auziere S, Gadkari A, Girolomoni $G$, Puig L, Simpson EL et al. Epidemiology of atopic dermatitis in adults: Results from an international survey. Allergy. 2018 Feb 13;73(6):1284-93. DOI: $10.1111 /$ all.13401.

14. Kantor R, Thyssen JP, Paller AS, Silverberg JI. Atopic dermatitis, atopic eczema, or eczema? A systematic review, meta-analysis, and recommendation for uniform use of atopic dermatitis. Allergy. 2016 Aug 3;71(10):1480-5. DOI: $10.1111 /$ all.12982.

15. Manti S, Chimenz R, Salpietro A, Colavita L, Pennisi P, Pidone C, et al. Atopic dermatitis: expression of immunological imbalance. J Biol Regul Homeost Agents. 2015 Apr-Jun;29(2) Suppl 1):13-7.

16. Belkaid Y, Tamoutounour S. The influence of skin microorganisms on cutaneous immunity. Nat Rev Immunol. 2016 May 27;16(6):353-66. DOI: $10.1038 /$ nri.2016.48.
17. Avena-Woods C. Overview of atopic dermatitis. Am J Manag Care. 2017 Jun;23 (8 Suppl): 115-123.

18. Woo TE, Sibley CD. The emerging utility of the cutaneous microbiome in the treatment of acne and atopic dermatitis. J Am Acad Dermatol. 2020;82(1):222-8. DOI: 10.1016/j.jaad.2019.08.078.

19. Blicharz L, Rudnicka L, Samochocki Z. Staphylococcus aureus: an underestimated factor in the pathogenesis of atopic dermatitis? Adv Dermatol Allergol. 2019 Feb 22;36(1):11-7. DOI: 10.5114/ada.2019.82821.

20. Paller AS, Kong HH, Seed P. The microbiome in patients with atopic dermatitis. J Allergy Clin Immunol. 2019;143(1):26-35. DOI: 10.1016/j.jaci.2018.11.015.

21. Korostovtsev DS, Makarova IV, Revyakina VA, Gorlanov IA. [Index SCORAD - objective and standardized method of skin affection estimation with atopic dermatitis]. Allergology. 2000;3:39-43. Russian.

22. Larsen FS, Hanifin JM. Epidemiology of atopic dermatitis. Immunol Allergy Clin N Amer. 2002;22(1):1-24. DOI: 10.1016/S0889. 8561(03)00066-3.

23. Yarilin AA. [Immunology basis]. Moscow: Medicine; 1999. 608 p. Russian.

24. Kutasevych YaF, Dzhoraeva SK, Goncharenko VV. [Comparative analysis of clinical and anamnestic features of the course of atopic dermatitis and true eczema, complicated by staphylococcal infection]. Dermatology and Venereology. 2020 Mar 10; 1(87):8-16. DOI: 10.33743/2308-1066-2020-1-8-16. Ukrainian.

25. Dzhoraeva S, Sobol N, Ivantsova $H$. Phenotypical characteristics of the biological properties of staphylococci withdrawn from patients with allergic dermatitis. Eureka: Health Science. 2020 Jan 31; 1:15-21.

DOI: $10.21303 / 2504-5679.2020 .001125$. 


\section{Изучение показателей} противомикробной резистентности у больных аммергодерматозами, отягощенными стафилококковой инфекцией, по результатам тестов с аутоштаммами

\section{Я. Ф. Кутасевич, С. К. Джораева , В. В. Гончаренко, И. А. Маштакова, Е. В. Щёголева, Н. В. Соболь \\ ГУ «Інститут дерматологии и венерологии НАМН Украинь», ул. Чернышевская 7/9, Харьков 61057, Украина}

Вступление. Актуальность исследования обусловлена отсутствием данных о состоянии неспецифического клеточного иммунитета в исследованиях с сыворотками и аутоштаммами S.aureus, выделенными от больных аллергодерматозами, которые отражали бы напряженность противомикробного иммунитета у пациентов с аллергодерматозами, отягощенными стафилококковой инфекцией, в зависимости от степени тяжести дерматоза.

Цель: определение и анализ результатов показателей противомикробного иммунитета у больных атопическим дерматитом и истинной экземой, отягощенных стафилококковой инфекцией, с использованием сывороток и аутоштаммов S. aureus, в зависимости от степени тяжести заболеваний.

Материал и методы. В исследование было включено 107 пациентов с аллергодерматозами разной степени тяжести и 15 практически здоровых особ контрольной группы. Больные были разделены на три группы в зависимости от тяжести течения кожного процесса. У них были определены основные показатели начальных стадий фагоцитоза и кислородзависимой бактерицидной активности фагоцитов. Для оценки противомикробного иммунитета проведены иммунологические исследования с использованием собственных штаммов пациентов, выделенных из очагов поражения, и эталонного штамма S. aureus ATCC 25923.

Результаты. Оценка показателей фагоцитоза у больных аллергодерматозами показала корреляцию между степенью тяжести заболевания и уровнем подавления клеточного звена неспецифического иммунитета. По результатам исследований с исполь- зованием аутоштаммов $S$. aureus наиболее существенное угнетение фагоцитоза ( $p \leq 0,05)$, по сравнению со значениями аналогичных показателей в контрольной когорте здоровых лиц, установлено в группах больных с умеренным и тяжелой степенью тяжести атопического дерматита (АД), соответственно: фагоцитарная активность (ФА) $(78,1 \pm 1,4) \%$ и $(72,4 \pm 1,4) \%$ и $(71,7 \pm 0,8) \%$; фагоцитарное число (ФЧ) $(5,3 \pm 0,2)$ абсолютного числа (абс. ч.) и $(4,3 \pm 0,2)$ абс. ч. и $(3,5 \pm 0,1)$ абс. ч.; фагоцитарный индекс $(Ф И)(6,8 \pm 0,2)$ абс. ч. и $(6,2 \pm 0,2)$ абс. ч. и $(4,8 \pm 0,1)$ абс. ч.; фагоцитарная емкость $(Ф \mathrm{E})(30,3 \pm 1,0) \times 10^{3}$

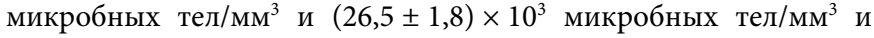
$(22,6 \pm 0,8) \times 10^{3}$ микробных тел $/$ мм $^{3}$; спонтанный тест обновления нитросинего тетразолия (сНСТ) $(42,1 \pm 1,3) \%$ и $(48,1 \pm 1,2) \%$ и $(50,6 \pm 0,3) \%$; индуцированный тест обновления нитросинего тетразолия (иНСТ) $(63,4 \pm 1,6) \%$ и $(53,4 \pm 0,8) \%$ и $(51,7 \pm 0,7) \%$. У больных истинной экземой (ИЭ) выявлено подобную закономерность угнетения фагоцитоза, наиболее выраженную у пациентов с тяжелой степенью тяжести заболевания $(p \leq 0,05)$, но с несколько меньшей степенью отличия значений показателей фагоцитоза по сравнению с группой здоровых лиц, соответственно: ФА $(74,8 \pm 1,3) \%$ и $(78,1 \pm 1,4) \%$; ФЧ $(4,5 \pm 0,1)$ абс. ч. и $(5,3 \pm 0,2)$ абс. ч.; ФИ $(5,9 \pm 0,2)$ абс. ч. и $(6,8 \pm 0,9)$ абс. ч.; сНСТ $(46,0 \pm 0,6) \%$ и $(42,1 \pm 1,3) \%$; иНСТ $(51,8 \pm 0,8) \%$ и $(63,4 \pm 1,6) \%$.

Выводы. Результаты определения показателей фагоцитоза у больных аллергодерматозами с использованием эталонной культуры S. aureus ATCC 25923 в целом отражают описанные закономерности угнетения у пациентов клеточного звена неспецифического иммунитета, но являются менее презентабельными для их обнаружения по сравнению с аутоштаммами.

Ключевые слова: аллергодерматозы, тяжесть течения, аутоштаммы S. aureus, S. aureus ATCC 25923, противомикробная резистентность.

Для цитирования: Кутасевич ЯФ, Джораева СК, Гончаренко ВВ, Маштакова ИА, Щёголева ЕВ, Соболь НВ. Изучение показателей противомикробной резистентности у больных аллергодерматозами, отягощенными стабилококковой инфекиией, по результатам тестов с аутоштаммами. Журнал Национальной академии медицинских наук Украинь. 2021;27(2):73-80. https:/doi.org/10.37621/JNAMSU-2021-2-1.

Статья поступила в редакцию 30.04 .202 | Направлена на рецензирование 12.07.2021 | Принята в печать 15.07.2021 